\title{
Problematika Pengelolaan Tanah Wakaf: Konsep Klasik dan Keterbatasan Inovasi Pemanfaatannya di Indonesia
}

\author{
Agus Triyanta dan Mukmin Zakie \\ Fakultas Hukum Universitas Islam Indonesia \\ J1. TamansiswaNo. 158 Yogyakarta \\ triyantaagus@yahoo.com dan zakie_fh@yahoo.co.id
}

\begin{abstract}
This study raises the issue on; first, how is the classic concept of waqaf land and the use of waqaf land in Islamic law or muamalah jurisprudence? Secondly, how is the utilization of donated land and its contribution to the welfare of the people in Indonesia? This is a normative study combined with field research. The data were collected through literatures, documentation studies, observations, and guided interviews. The study concluded; first, institution or charitable institutions have a role in the history and civilization of Muslims. Various institutions have functioned to serve as a dissemination of science and culture, and provide spaces for scholars, jurists and humanists to develop their knowledge and skills. Secondly, the use of donated land in Indonesia is dominated for the purposes of a place of worship, school infrastructure, other social endowments, land burial and educational boarding schools.
\end{abstract}

Keywords: Waqaf (endowments), land, fiqih (jurisprudence), Indonesia, utilization

\section{Abstrak}

Penelitian ini mengangkat permasalahan; pertama, bagaimanakah konsep klasik tentang tanah wakaf dan pemanfaatan tanah wakaf dalam hukum Islam atau fikih muamalah? Kedua, bagaimanakah pemanfaatan tanah wakaf dan kontribusinya bagi kesejahteraan masyarakat di Indonesia? Penelitian ini merupakan penelitian normatif yang dipadukan dengan penelitian lapangan (field research). Pengumpulan data melalui studi pustaka, studi dokumentasi, observasi dan wawancara terpimpin. Hasil penelitian menyimpulkan; pertama, institusi atau pranata wakaf memiliki peranan dalam perjalanan sejarah dan peradaban umat Islam. Berbagai lembaga wakaf telah berfungsi sebagai tempat penyebaran ilmu dan budaya, dan memberikan ruang bagi ulama, para ahli fikih dan budayawan untuk mengembangkan keilmuan dan keahliannya. Kedua, pemanfaatan tanah wakaf di Indonesia didominasi untuk keperluan tempat ibadah, prasarana sekolah, wakaf sosial lainnya, tanah pemakaman dan pendidikan pesantren.

Kata Kunci: Wakaf, tanah, fikih, Indonesia, pemanfaatan 


\section{Pendahuluan}

Wakaf adalah salah satu pranata yang sangat khas dalam Islam. Meski wakaf merupakan salah satu bentuk derma yang dikontribusikan oleh seorang muslim, namun sangat berbeda dengan konsep derma (philantropi) pada umumnya. Philantropi atau derma adalah nomenklatur yang sangat umum untuk menyebut adanya sebuah pemberian untuk kepentingan umum. Namun, di dalam Hukum Islam, atau lebih khususnya figh muamalah, ialah hukum Islam yang mengatur tentang hubungan antara orang, hak, kewajiban serta berbagai transaksi, terdapat berbagai macam model derma atau philantropi yang berbeda antara satu dengan yang lainnya.

Letak kekhasan wakaf, jika dibandingkan dengan derma pada umumnya, jika dilihat dari bentuk obyek yang diserahkan atau diberikan, wakaf haruslah berupa aset yang tetap utuh (baik benda bergerak maupun tidak bergerak). Wakaf adalah aset yang tidak habis karena pemakaian. Maka, makanan misalnya, tidak dapat dijadikan obyek wakaf. Untuk menjadi obyek wakaf adalah yang tidak habis karena pemakaian, misalnya tanah, bangunan, pohon, dan sebagainya. Juga dalam pemanfaatannya, wakaf hanya dapat dimanfaatkan untuk kepentingan umat. Meski demikian, kemudian berkembang konsep wakaf ahli, ialah yang pemanfaatannya untuk keluarga. Namun, intinya secara umum, wakaf dimanfaatkan bagi kepentingan umat secara umum.

Konsep wakaf yang semacam itu, dalam dataran implementasinya masih memerlukan banyak pengembangan. Karena, kecenderungan umum yang masih ada dan berlaku di Indonesia khususnya, wakaf masih sangat dimanfaatkan dan dikelola dengan sangat sederhana. Orientasi wakaf masih baru terbatas pada pemanfaatan yang berkaitan dengan ibadah dan belajar atau mengaji. Padahal, untuk menunjang keberlangsungan fungsi aset wakaf itu sendiri, diperlukan pembiayaan yang terkadang menjadikan terlantarnya aset wakaf karena ketiadaan biaya pemeliharaan. Sedangkan di sisi lain, pengembangan model pengelolaan wakaf mestinya dapat disentuh dengan inovasi-inovasi yang lebih dapat memberdayakan secara ekonomis. Untuk itulah penting dibahas berbagai model praktik pemanfaatan tanah wakaf yang ada di Indonesia, kelebihan dan kekurangannya, sehingga pada masa depannya, akan dapat 
dilakukan berbagai upaya terobosan yang lebih menghasilkan keuntungan yang optimal.

\section{Rumusan Masalah}

Melihat uraian dalam pendahuluan tersebut, maka permasalahan dapat dirumuskan sebagai berikut: pertama, bagaimanakah konsep klasik tentang tanah wakaf dan pemanfaatan tanah wakaf dalam hukum Islam umumnya atau fikih muamalah pada khususnya? Kedua, bagaimanakah pemanfaatan tanah wakaf dan kontribusinya bagi kesejahteraan masyarakat di Indonesia saat ini?

\section{Tujuan Penelitian}

Dari rumusan masalah di atas, ada beberapa tujuan dari penelitian ini. Secara rinci, tujuannya adalah sebagai berikut: pertama, untuk merumuskan batasan konseptual atas tanah wakaf dan pemanfaatan tanah wakaf dalam hukum Islam umumnya atau fikih muamalah pada khususnya. Kedua, untuk memformulasikan pola pemanfaatan tanah wakaf dan kontribusinya bagi kesejahteraan masyarakat di Indonesia saat ini, mengidentifikasi kelemahan dan kelebihannya.

\section{Metode Penelitian}

Fokus penelitian ini adalah mengetahui bagaimana pemanfaatan tanah wakaf dalam sejarah perjalanan umat Islam, serta bagiamanakah pemanfaatan tanah wakaf bagi kesejahteraan masyarakat muslim di Indonesia hari ini. Jenis penelitian ini adalah penelitian normatif yang dipadukan dengan penilitian lapangan (field research). Sehingga sumber bahan hukum dari penelitian ini terdiri dari; 1). Sumber hukum primer : bahan-bahan hukum yang mempunyai kekuatan hukum mengikat seperti Al-qur'an, al-hadits, kitab-kitab klasik, fatwa dewan syari'ah, undangundang, 2). Bahan hukum sekunder berupa literatur, jurnal dan data elektronik serta, 3). Bahan-bahan hukum tersier berupa kamus dan ensiklopedi. Di samping itu, 
sumber data dari penelitian ini juga berupa observasi dan wawancara ke berbagai lokasi pemanfaatan tanah wakaf.

Cara pengumpulan bahan hukum dilakukan melalui; 1). Studi pustaka, yakni dengan mengkaji berbagai peraturan (fatwa Dewan Syariah Nasional) atau literatur yang berhubungan dengan permasalahan yang akan diteliti, 2). Studi dokumen, yakni dengan mengkaji berbagai dokumen yang terkait dengan permasalahan yang akan diteliti, 3). Pengamatan atau observasi, dan 4) melalui wawancara terpimpin

Analisis hasil penelitian dilakukan dengan cara deskriptif-analitis. Data yang terkumpul dari studi kepustakawanan, dianalisis dengan metode kualitatif, yaitu data-data yang diperoleh dari hasil penelitian dikelompokan dan dipilih, kemudian dihubungkan dengan masalah yang akan diteliti.

\section{Hasil Penelitian dan Pembahasan}

\section{Dinamika Pemanfaatan Tanah Wakaf}

Hari ini, umat Islam hidup dalam era lebih kurang 1400 tahun dari kelahiran agamanya yang dibawa oleh Nabi Muahammad saw. Dengan berbekal ajaran yang disampaikan Nabi tersebut, umat Islam dituntut dan ditantang untuk dapat hidup dengan sejahtera secara spiritual maupun material. Karena itulah,maka berbagai ajaran Nabi harus diberdayakan dan dioptimalkan bagi kemajuan dan kesejahteraan umat Islam. Berbagai pembaharuan (reaktualisasi) harus dilakukan dalam batasbatas yang memungkinkan. Kejayaan Islam masa lalu tidak terlepas dari pemberdayaan ajaran agama yang ada pada ketika itu. Di antara ajaran tersebut adalah syariat terkait wakaf. ${ }^{1}$

Di sinilah urgensi pewakafan tanah mengemuka, ialah sebagai sebuah solusi bagi masyarakat muslim untuk dapat mengupayakan terwujudnya pemenuhan terhadap kebutuhan masyarakat dan kebutuhan dalam hal-hal terkait kegiatan keagamaan. Sehingga, wakaf meniscayakan adanya solusi keumatan yang belum tentu dijumpai konsep serupa dalam masyarakat lain.

1 Agus Triyanta, "Wakaf Produktif:Dari Muamalah Klasik Menuju Inovasi Kontemporer." Makalah Disampaikan dalam Workshop Pengelolaan Wakaf Produktif (Pendekatan Pemberdayaan Kaum Mustadh'afin) pada tanggal 2 Agustus 2009 di Aula DPRD Kabupaten Sleman, diselenggarakan oleh Yayasan Ikhtiar Sejahtera, Tempel, Sleman. hlm. 1. 


\section{Pengertian dan Bentuk Wakaf}

Wakaf berasal dari bahasa Arab waqf yang kemudian telah diserap dalam bahasa Indonesia menjadi wakaf. Kata ini berasal dari kata kerja bahasa arab وقفا berarti “berdiri, berhenti. ${ }^{2}$ Kata wakaf sering disebut juga dengan habs. ${ }^{3}$ Dengan demikian, kata wakaf itu dapat berarti berhenti, menghentikan dan dapat pula berarti menahan. Pengertian menahan dihubungkan dengan harta kekayaan, itulah yang dimaksud wakaf dalam bahasa ini.

Menurut terminologi syariat Islam, wakaf berarti, " menyerahkan suatu hak milik yang tahan lama zatnya kepada seorang nadzir (penjaga wakaf) atau kepada suatu badan pengelola, dengan ketentuan bahwa hasil atau manfaatnya digunakan kepada hal-hal yang sesuai dengan ajaran syari'at Islam." 4 Yang penting untuk ditegaskan adalah bahwa benda yang diwakafkan bukan lagi hak milik yang mewakafkan, dan bukan pula hak milik tempat menyerahkan, tetapi ia menjadi hak milik Allah (hak umum). Sehingga dengan adanya ikrar wakaf, maka terlepaslah sudah hubungan hukum kepemilikan benda tersebut dari pemilik awalnya.

Jika ditinjau dari segi jangka waktu atau keberlanjutannya, wakaf ini dibagi dua (2), yaitu : wakaf abadi dan wakaf sementara. Wakaf abadi ialah wakaf yang diikrarkan untuk jangka waktu tidak terbatas dan tetap berlanjut sepanjang zaman. Wakaf model ini dapat dimanfaatkan dalam jangka waktu yang panjang, tidak habis dalam sekali pakai, hal ini dikarenakan wakaf itu lebih mementingkan manfaat dari benda tersebut.

Jika diamati lebih seksama, maka wakaf yang sebenarnya dalam Islam adalah wakaf abadi, yang pahalanya berlipat ganda dan terus berjalan selama wakaf itu masih ada. Pahala wakaf ini mengalir untuk pewakaf selama wakafnya terus berlangsung. Wakaf ini adalah yang biasa disebut sebagai shadaqah jariyah yang paling sempurna bentuknya.

2A.W. Munawir, Kamus Al-Munawir Arab-Indonesia, Pustaka Progresif, Yogyakarta, 1994, hlm. 1576. Lihat juga dalam Mahmud Yunus, Kamus Arab-Indonesia, Yayasan penyelenggara penterjemah/penafsir Al-Qur'an RI, 1973, hlm. 505.

${ }^{3}$ Muhammad Jakarta Fadlullah. B.T.H , Brendgeest,.Kamus Arab-Melayu, Balai Pustaka, Jakarta, 1925, Jilid I, hlm. 116. Sayyid Sabiq, Fiqih Sunnah, Al-Ma'arif, Bandung, 1997, hlm. 148.

${ }^{4}$ Harun Nasution, et all. Ensiklopedi Islam Indonesia, Djambatan, Jakarta, 1992, hlm. ... Lihat juga dalam Muhammad Daud Ali, Sistem Ekonomi Islam Zakat dan Wakaf, UI-Press, Jakarta, 1988, hlm. 80 
Wakaf sementara ialah wakaf yang sifatnya terbatas waktunya dan tidak abadi, baik dikarenakan oleh bentuk barangnya maupun keinginan wakif sendiri. ${ }^{5}$ Dari segi penggunaan harta yang diwakafkan, wakaf bisa dibagi menjadi: mubasyir/dzati (harta wakaf yang menghasilkan pelayanan masyarakat dan bisa digunakan secara langsung seperti madrasah dan rumah sakit) dan istitsmary (harta wakaf yang ditujukan untuk penanaman modal dalam produksi barang-barang dan pelayanan yang dibolehkan syara' dalam bentuk apapun kemudian hasilnya diwakafkan sesuai keinginan waqif). ${ }^{6}$

\section{Pendayagunaan Tanah Wakaf dalam Sejarah Islam}

Institusi atau pranata wakaf memiliki peranan dalam perjalanan sejarah dan peradaban umat Islam. Berbagai lembaga wakaf telah berfungsi sebagai tempat penyebaran ilmu dan budaya, dan memberikan ruang bagi ulama, para ahli fikih dan budayawan untuk mengembangkan keilmuan dan keahliannya. Di antara lembaga-lembaga wakaf yang memiliki fungsi tersebut sebagai berikut:

Pertama, untuk tempat ibadah (masjid). Masjid wakaf yang pertama kali berdiri adalah masjid Quba, yang didirikan oleh Rasulullah SAW saat pertama kali menginjakkan kakinya di Madinah, kemudian Masjid Nabawi yang didirikan tahun pertama Hijriah, kemudian bermunculan masjid-masjid wakaf pada masa Khulafā` al-Rasyidin, Bani Umayyah dan Bani al-'Abbas. Ibnu Bathutah menggambarkan akitivitas ilmu yang terjadi di masjid pada masa itu, di mana masjid-masjid mengadakan halaqah-halaqah yang mengajarkan bermacam-macam ilmu pengetahuan. Para ahli hadits membacakan hadits di atas bangku yang tinggi, dan membaca al-Qur'an dengan bacaan yang bagus setiap pagi dan sore. Beberapa kelompok guru mentalqinkan bacaan al-Qur'an kepada anak-anak kecil, mereka tidak menulis al-Qur'an di papan tulis karena takut merusak citra al-Qur'an. Pengajar ilmu menulis, mengajarkan cara menulis syair, sehingga anak-anak setelah belajar membaca, mereka kemudian belajar menulis.

Bersamaan dengan peranan masjid sebagai pusat pengajaran dan dakwah Islam, di sekitar masjid berdiri asrama-asrama yang menampung orang-orang

\footnotetext{
${ }^{5}$ Mundzir Qahaf, Op. Cit., hlm. 25

${ }^{6}$ Mundir Qohaf, Al-Waqof al-Islami, Dar al-Fikr, cet I, Beirut, tt., hlm.158-159.
} 
miskin ataupun penuntut Ilmu yang berasal dari tempat yang jauh,yang dikenal dengan istilah Rubath, Khaniqah, Zawayah dan Khalawy.?

Kedua, untuk al-Katatib (Pusat Baca Tulis). Al-Kuttab atau al-maktab merupakan tempat bagi anak- anak usia dini ataupun pemula yang ingin belajar membaca dan menulis, belajar al-Qur'an, dan dasar-dasar ilmu-ilmu agama. Pada masa bani Umayyah, al-katatib, diperuntukkan bagi anak-anak khalifah dan keluarga istana serta orang kaya, akan tetapi selanjutnya bermunculan al-katatib yang didirikan oleh para dermawan sebagai wakaf untuk anak-anak yatim, anakanak miskin. Ibnu Huql mencatat dalam satu kota seperti Sicilia berdiri 300 alkatatib, yang dalam satu al-kuttab menampung ratusan bahkan ribuan siswa. ${ }^{8}$

Ketiga, untuk Madrasah (Sekolah). Madrasah yang dibiayai dengan harta wakaf yang terkenal dalam sejarah Islam adalah madrasah al-Nizhamiyah di Baghdad yang didirikan oleh Bani Saljuk Turki tahun $459 \mathrm{H}$. Tujuan pendirian madrasah ini menurut Nizham al-Mulk untuk mencetak pemuda-pemuda calon pemimpin bangsa yang memiliki ilmu atas dasar akidah ahlus-sunnah. Kemunculan madrasah al- Nizhamiyah yang didanai dengan dana wakaf diikuti dengan berdirinya madrasah-madrasah yang lain diberbagai negara Islam, seperti madrasah wakaf al-Nuriyah di Suriah, yang didirikan oleh Nuruddin al-Zanki, madrasah wakaf al- Zhahiriyah yang didirikan oleh al-Zhahir Beybers di Kairo tahun $626 \mathrm{H}$, Madrasah al-Shalihiyyah yang merupakan wakaf raja al-Shalih Najm al-Din Ayyub di Mesir tahun $641 \mathrm{H}$, Madrasah al-Mas'udiyah yang didirikan oleh Mas'ud alSyafi'i di Baghdad. Madrasah ini mengajarkan fikih empat madzhab disamping ilmu-ilmu umum dan kedokteran. Lalu ada madrasah al-Shalahiyah di Halb yang didirikan Amir Shalahuddin Yusuf al-Dawadar, madrasah al-Ghiyats atau madrasah al-Malik Manshur di Mekkah, yang didirikan al- Manshur Ghiyats al-Din tahun 813 H. Ada juga madrasah- madrasah lain yang dibangun dan dibiayai operasionalnnya dengan dana wakaf, seperti madrasah al-Mustanshiriyah di Baghdad, madrasah Sulthan Hasan, Jami' al-Azhar di Mesir, al-Zaitunah di Tunis, al-Qurawiyyin di Fes Maroko.9 Al-Jami' al-Azhar merupakan masjid sekaligus lembaga pendidikan yang

${ }^{7}$ Muhammad ibn Ahmad ibn Shalih al-Shalih, al-Waqfi al-Syari'ah wa Atsrubu fi Tanmiyah al-Mujtama', Fihrisah Maktabah al-Malik Fahd al-Wathaniyah, Saudi Arabia, 2001, hlm. 175

${ }^{8}$ Mushtafa al-Siba’i, Min Rawa ${ }^{\prime}$ Hadaratina, Dar al-Warraq, 1420 H, hlm. 199-204

${ }^{9}$ Muhammad ibn Ahmad ibn Shalih al-Shalih, Op. Cit., hlm. 184-187 
didirikan oleh Jauhar al-Shaqily (panglima pasukan Mu'izli Dinillah al-Fathimy) pada tahun 359 H. Nama al-Azhar diambil dari Fatimah al-Zahra.

Keempat, untuk Maktabah (Perpustakaan). Lembaga berbasis wakaf lain yang memiliki peran dalam pembentukan intelektual umat Islam adalah maktabah atau perpustakaan. Maktabah memiliki nama lain seperti khizanah al-kutub, bait alhikmah, dar al-ilm, dar al-kutub. Maktabah tersebar hampir di seluruh penjuru dunia Islam sejak abad ke-4. Maktabah menjadi kiblat bagi penuntut ilmu, karena membantu mereka dalam memperoleh ilmu pengetahuan lewat buku-buku dengan gratis. Maktabah yang didanai dengan harta wakaf yang terkenal dalam sejarah Islam diantaranya adalah : 1). Dar al-'Ilm di Mosul (abad ke-4 Hijriah); 2). Dar al-Ilm di Baghdad (tahun 381 H); 3). Dar al-Hikmah di Kairo (tahun 395 H). ${ }^{10}$

\section{Bentuk Pemanfaatan Tanah Wakaf di Indonesia}

Tanah wakaf di Indonesis sebenarnya jumlahnya sangat banyak dan dengan luasan yang sangat besar. Menurut statistik dari Bimas Islam Kementerian Agama Republik Indonesia, luas tanah wakaf di Indonesia mencapai $80.824 .725 \mathrm{~m}^{2}$. Tanah wakaf ini tersebar di berbagai wilayah di seluruh penjuru Indonesia. Secara rinci, berikut ini statistik perwakafan di Indonesia:

Tabel 1

Data Wakaf Umum Per-Propinsi se Indonesia11

\begin{tabular}{|l|l|r|r|r|r|r|}
\hline No & \multicolumn{1}{|c|}{ Provinsi } & $\begin{array}{c}\text { LUAS } \\
\text { (dalam m2) }\end{array}$ & $\begin{array}{c}\text { Sudah } \\
\text { Sertifikat }\end{array}$ & $\begin{array}{c}\text { Belum } \\
\text { Sertifikat }\end{array}$ & Sudah AIW & Belum AIW \\
\hline 1 & ACEH & 3.256 .211 & $598.128,50$ & $1.263 .890,05$ & $1.262 .290,05$ & $1.600,00$ \\
\hline 2 & SUMATERA UTARA & 1.968 .116 & $80.411,07$ & $154.203,75$ & $153.733,75$ & 470 \\
\hline 3 & SUMATERA BARAT & 295.081 & $129.634,00$ & $23.431,82$ & $23.431,82$ & 0 \\
\hline 4 & RIAU & 229.457 & $80.147,00$ & $150.297,95$ & $143.537,95$ & $6.760,00$ \\
\hline 5 & JAMBI & 862.191 & $628.738,00$ & $239.425,60$ & $159.510,10$ & $79.915,50$ \\
\hline 6 & SUMATERA SELATAN & 524.250 & $127.940,00$ & $401.360,59$ & $396.660,59$ & $4.700,00$ \\
\hline 7 & BENGKULU & 424.479 & 0 & $424.479,00$ & $424.479,00$ & 0 \\
\hline 8 & LAMPUNG & 20.134 .697 & $137.190,40$ & $7.507,00$ & $7.127,00$ & 380 \\
\hline 9 & KEP. BANGKA & 626.693 & $491.672,00$ & $135.021,00$ & $94.324,00$ & $40.697,00$ \\
\hline 10 & KELITUNG & 620.791 & $294.990,79$ & $349.675,99$ & $349.675,99$ & 0 \\
\hline 11 & DKI JAKARTA & 461.941 & $169.334,54$ & $39.652,81$ & $39.652,81$ & 0 \\
\hline
\end{tabular}

10 Yaqut ibn Abdullah al-Hamawy, Mu'jam al-Udaba', Dar al- Ma’mun, Kairo, 1938 ,7/192

${ }^{11}$ Diolah dari statistik wakaf pada http://simbi.kemenag.go.id/siwak/ akses, 1 September 2014 
Agus T. dan Mukmin Z. Problematika Pengelolaan Tanah... 591

\begin{tabular}{|c|c|c|c|c|c|c|}
\hline 12 & JAWA BARAT & 14.259 .818 & $3.391 .237,25$ & $2.881 .373,46$ & $2.879 .272,00$ & $2.101,46$ \\
\hline 13 & JAWA TENGAH & 7.724 .825 & $3.205 .819,83$ & $869.417,55$ & $783.852,55$ & $85.565,00$ \\
\hline 14 & DI YOGYAKARTA & 1.848 .592 & $1.367 .198,25$ & $56.424,50$ & $56.204,50$ & 220 \\
\hline 15 & JAWA TIMUR & 12.171 .292 & $706.117,38$ & $509.494,31$ & $509.494,31$ & 0 \\
\hline 16 & BANTEN & 837.917 & $42.340,71$ & $438.812,98$ & $333.977,48$ & $104.835,50$ \\
\hline 17 & BALI & 1.957 .400 & $1.750 .934,89$ & $206.464,61$ & $131.807,61$ & $74.657,00$ \\
\hline 18 & NTB & 2.802 .974 & $1.799 .914,00$ & $998.688,00$ & $998.688,00$ & 0 \\
\hline 19 & NTT TIMUR & 746.425 & $373.381,00$ & $373.043,75$ & $356.102,00$ & $16.941,75$ \\
\hline 20 & KALIMANTAN BARAT & 384.620 & $135.332,10$ & $215.404,84$ & $168.054,84$ & $47.350,00$ \\
\hline 21 & $\begin{array}{l}\text { KALIMANTAN } \\
\text { TENGAH }\end{array}$ & 300.451 & $28.231,55$ & $5.029,87$ & $5.029,87$ & 0 \\
\hline 22 & $\begin{array}{l}\text { KALIMANTAN } \\
\text { SELATAN }\end{array}$ & 2.221 .960 & $2.076 .171,70$ & $145.579,23$ & $139.171,23$ & $6.408,00$ \\
\hline 23 & KALIMANTAN TIMUR & 824.659 & $298.490,23$ & $521.425,24$ & $521.101,24$ & 324 \\
\hline 24 & SULAWESI UTARA & 296.100 & 0 & $111.679,46$ & $111.679,46$ & 0 \\
\hline 25 & SULAWESI TENGAH & 37.204 & $30.086,00$ & $7.118,00$ & $7.118,00$ & 0 \\
\hline 26 & SULAWESI SELATAN & 586.524 & $169.692,78$ & $407.247,17$ & $401.616,49$ & $5.630,68$ \\
\hline 27 & $\begin{array}{l}\text { SULAWESI } \\
\text { TENGGARA }\end{array}$ & 276.121 & $189.902,00$ & $86.219,00$ & $86.219,00$ & 0 \\
\hline 28 & GORONTALO & 72.172 & $13.879,87$ & $44.662,00$ & $28.991,00$ & $15.671,00$ \\
\hline 29 & SULAWESI BARAT & 2.802 .974 & $216.509,00$ & $3.513 .626,31$ & $1.108 .353,79$ & $2.405 .272,52$ \\
\hline 30 & MALUKU & 6.549 & $5.604,00$ & 0 & 0 & 0 \\
\hline 31 & MALUKU UTARA & 533.331 & $533.331,00$ & 0 & 0 & 0 \\
\hline 32 & PAPUA & 565.454 & $201.616,83$ & $363.836,75$ & $3.069,00$ & $360.767,75$ \\
\hline \multirow[t]{2}{*}{33} & PAPUA BARAT & 163.457 & $19.560,00$ & $143.897,00$ & $2.500,00$ & $141.397,00$ \\
\hline & $\mathrm{Jumlah}$ & 80.824 .725 & & & & \\
\hline
\end{tabular}

Dari tabel di atas nampak bahwa sebaran tanah wakaf ada di seluruh propinsi di Indonesia, meskipun dengan tingkat yang berbeda-beda. Untuk melihat urutan di propinsi mana yang memiliki tanah wakaf yang paling luas, tabel berikut dapat menunjukkan dengan jelas.

Tabel 2

Luas Tanah Wakaf Per-Propinsi dengan Urutan Terluas ${ }^{12}$

\begin{tabular}{|l|l|r|}
\hline No & Provinsi & \multicolumn{1}{c|}{ Data Luas Total } \\
\hline 1 & LAMPUNG & 20.134 .697 \\
\hline 2 & JAWA BARAT & 14.259 .818 \\
\hline 3 & JAWA TIMUR & 12.171 .292 \\
\hline 4 & JAWA TENGAH & 7.724 .825 \\
\hline 5 & ACEH & 3.256 .211 \\
\hline 6 & NUSA TENGGARA BARAT & 2.802 .974 \\
\hline 7 & SULAWESI BARAT & 2.802 .974 \\
\hline
\end{tabular}

${ }^{12}$ Diolah dari statistik wakaf pada http://simbi.kemenag.go.id/siwak/ akses, 1 September 2014 
592 Jurnal Hukum IUS QUIA IUSTUM NO. 4 VOL. 21 OKTOBER 2014: 583 - 606

\begin{tabular}{|l|l|r|}
\hline 8 & KALIMANTAN SELATAN & 2.221 .960 \\
\hline 9 & SUMATERA UTARA & 1.968 .116 \\
\hline 10 & BALI & 1.957 .400 \\
\hline 11 & DI YOGYAKARTA & 1.848 .592 \\
\hline 12 & JAMBI & 862.191 \\
\hline 13 & BANTEN & 837.917 \\
\hline 14 & KALIMANTAN TIMUR & 824.659 \\
\hline 15 & NUSA TENGGARA TIMUR & 746.425 \\
\hline 16 & KEP. BANGKA BELITUNG & 626.693 \\
\hline 17 & KEPULAUAN RIAU & 620.791 \\
\hline 18 & SULAWESI SELATAN & 586.524 \\
\hline 19 & PAPUA & 565.454 \\
\hline 20 & MALUKU UTARA & 533.331 \\
\hline 21 & SUMATERA SELATAN & 524.250 \\
\hline 22 & DKI JAKARTA & 461.941 \\
\hline 23 & BENGKULU & 424.479 \\
\hline 24 & KALIMANTAN BARAT & 384.620 \\
\hline 25 & KALIMANTAN TENGAH & 300.451 \\
\hline 26 & SULAWESI UTARA & 296.100 \\
\hline 27 & SUMATERA BARAT & 295.081 \\
\hline 28 & SULAWESI TENGGARA & 276.121 \\
\hline 29 & RIAU & 229.457 \\
\hline 30 & PAPUA BARAT & 163.457 \\
\hline 31 & GORONTALO & 72.172 \\
\hline 32 & SULAWESI TENGAH & \\
\hline 33 & MALUKU & $\mathbf{8 0 . 8 2 4 . 7 2 5}$ \\
\hline & J u m 1 a h & \\
\hline & & \\
\hline
\end{tabular}

Dari ragaan di atas, nampak bahwa tanah wakaf yang paling luas terdapat di Propinsi Lampung, ialah seluas $20.134 .697 \mathrm{~m}^{2}$, atau setara dengan 201 hekar lebih. Hal ini merupakan aset yang sangat besar bagi umat Islam. Sedangkan yang kedua adalah Jawa Barat dengan luas 14.259.818 $\mathrm{m}^{2}$. Baru kemudian yang ketiga disusul oleh Jawa Timur dengan luasan 12.171.292 m². Juga Sumatera Barat, sebuah wilayah yang sangat dikenal religius, bahkan memiliki kultur yang sangat dekat dengan Islam, ialah adat bersandi syara dan syara bersandi kitabullah, ternyata juga berada pada urutan-urutan bawah dari keseluruhan propinsi yang ada.

Sedangkan tiga propinsi dengan tanah wakaf yang paling kecil adalah Maluku dengan luas $6.549 \mathrm{~m}^{2}$, Kemudian urutan kedua dari bawah adalah Sulawesi 
Tengah, dengan luas $37.204 \mathrm{~m}^{2}$. Baru kemudian urutan ketiga dari bawah ialah Gorontalo dengan luas $72.172 \mathrm{~m}^{2}$.

Dengan melihat hal tersebut, ternyata tidak secara otomatis bahwa wilayah yang secara sosiologis memiliki kultur Islam mesti memiliki lahan tanah wakaf yang besar atau luas, misalnya saja Gorontalo, wilayah yang dikenal dengan komunitas Muslim dan kultur Islam yang relatif dominan ternyata pada posisi yang rendah dalam hal luasan tanah wakaf. Sumatera Barat, berdasar data statistik di atas, menempati urutan ke 7 dari bawah. Ini juga suatu hal yang menarik. Sumatera Barat dikenal dengan penyokong syariat Islam, yang sangat identik dengan asal muasal adagium, "adat bersandi syara' dan syara' bersandi kibatullah." Kesimpulan sementara yang dapat diambil adalah bahwa dominasi Islam secara sosio dan kultural ternyata tidak selalu berbanding lurus dengan luasnya tanah wakaf. Indikasi yang dapat dibaca adalah bahwa tauhid dan fikih sosial belum menjadi bagian integral dari pemahaman ajaran Islam secara umum.

Di luar apa yang terpaparkan di atas, ada fakta yang cukup menarik setelah peneliti mencermati data setiap propinsi yang lebih rinci. Fakta yang dimaksud adalah:13 1). Di Propinsi Lampung, propinsi dengan tanah wakaf terluas secara nasional, terdapat satu (1) orang yang memberikan wakaf dengan total luas tanah mencapai sekitar 200 hektar. Hal ini tentu menunjukkan adanya kesadaran yang sangat tinggi tentang wakaf. 2). Di Propinsi Jawa Barat, dijumpai fakta bahwa satu (1) orang memiliki 30 persil wakaf. Sekali lagi hal ini juga menunjukkan bahwa kesadaran berwakaf telah menjadi suatu kenyataan yang tidak dapat dipungkiri. Hal ini memberikan gambaran yang lebih konkrit tentang bagaimana tauhid dan fiqkih sosial telah menjadi suatu pemahaman umum. 3). Di Propinsi Yogyakarta, dalam data statistik yang ada telah menunjukkan sajian informasi yang lebih detail, ialah bahwa dalam tanah wakaf yang ada dikemukakan dengan jelas kepemilikan dari organisasi massa Islam terbesar, ialah apakah sebidang tanah tersebut milik Muhammadiyah ataukah tanah tersebut dimiliki oleh Nahdhatul Ulama (NU). 4). Khusus untuk data di Propinsi Jawa Timur, terkait dengan Pondok Modern Darussalam Gontor Ponorogo, kepemilikan banyak diatasnamakan KH Ahmad

${ }^{13}$ Disimpulkan dari data olahan setiap propinsi dari statistik wakaf pada http://simbi.kemenag.go.id/siwak/ akses, 1 September 2014 
Sahal. Tentu saja hal ini cukup menjadi perhatian, mengingat kekayaan atau aset wakaf yang dimiliki oleh Pondok Gontor tersebut sangat besar. Sehingga penggunaan nama perorangan seperti itu memerlukan kelengkapan administrasi tambahan yang dapat menunjukkan bahwa nama orang yang tercantum dalam akta yang ada tidak berarti secara pribadi, namun kelembagaan.

Dari catatan fakta menarik tersebut dapat ditarik suatu kesimpulan bahwa adanya wakaf satu orang dengan luasan yang sangat besar di Propinsi Lampung serta adanya seorang pewakaf yang mewakafkan 30 persil bidang tanah wakaf tersebut menunjukkan bahwa mengapa dua propinsi tersebut menduduki urutan pertama dan kedua dalam hal luasan tanah wakaf, memang kesadaran masyarakat muslim di wilayah tersebut sudah tinggi.

Pemanfaatan tanah wakaf merupakan suatu aspek yang sangat penting. Hal ini dikarenakan dengan model-model yang ditempuh atau dipilih bagi pengelolaan dan pemanfaatan tanah wakaf akan sangat tergantung pada tingkat pemahaman keberagamaan. Berikut ini tabel yang merupakan sajian data dari pemanfaatan atau peruntukan tanah wakaf di Indonesia:

\begin{tabular}{|c|c|c|c|c|c|c|c|c|c|c|c|}
\hline Provinsi & Luas & $\begin{array}{c}\text { Wakaf } \\
\text { Masjid / } \\
\text { Mshola }\end{array}$ & $\%$ & $\begin{array}{l}\text { Wakaf } \\
\text { Makam }\end{array}$ & $\%$ & $\begin{array}{c}\text { Wakaf } \\
\text { Pesantren }\end{array}$ & $\%$ & $\begin{array}{c}\text { Wakaf } \\
\text { SekoLah }\end{array}$ & $\%$ & $\mid \begin{array}{c}\text { Wakaf } \\
\text { Sosial Lain }\end{array}$ & $\%$ \\
\hline $\mathrm{ACEH}$ & 3.256 .211 & 537.019 & 0,16 & 315.275 & 0,10 & 1.661 .259 & 0,51 & 248.037 & 0,08 & 494.621 & 0,15 \\
\hline SUMATERA UTARA & 1.968 .116 & 952.631 & 0,48 & 560.721 & 0,28 & 27.168 & 0,01 & 149.384 & 0,08 & 278.212 & 0,14 \\
\hline SUMATERA BARAT & 295.081 & 152.618 & 0,52 & 21.416 & 0,07 & 4.947 & 0,02 & 56.336 & 0,19 & 59.764 & 0,20 \\
\hline RIAU & 229.457 & 104.543 & 0,46 & 25.785 & 0,11 & 52.500 & 0,23 & 14.622 & 0,06 & 32.007 & 0,14 \\
\hline JAMBI & 862.191 & 277.575 & 0,32 & 400.550 & 0,46 & 14.396 & 0,02 & 98.743 & 0,11 & 70.927 & 0,08 \\
\hline SUMATERA S & 524.250 & 122.691 & 0,23 & 176.349 & 0,34 & 15.000 & 0,03 & 161.186 & 0,31 & 49.024 & 0,09 \\
\hline BENGKULU & 424.479 & 109.632 & 0,26 & 104.416 & 0,25 & 15.226 & 0,04 & 66.401 & 0,16 & 128.804 & 0,30 \\
\hline LAMPUNG & 0.134 .697 & 20.074 .284 & 1,00 & 0 & 0,00 & 8.935 & 0,00 & 6.635 & 0,00 & 51.478 & 0,00 \\
\hline KEP. BANGKA BELITUNG & 626.693 & 52.102 & 0,08 & 368.990 & 0,59 & 141.568 & 0,23 & 70.510 & 0,11 & 3.035 & 0,00 \\
\hline KEPULAUAN RIAU & 620.791 & 287.333 & 0,46 & 184.583 & 0,30 & 70.510 & 0,11 & 68.283 & 0,11 & 17.232 & 0,03 \\
\hline DKI JAKARTA & 461.941 & 424.568 & 0,92 & 0 & 0,00 & 90 & 0,00 & 18.672 & 0,04 & 17.851 & 0,04 \\
\hline JAWA BARAT & 14.259 .818 & 7.327 .131 & 0,51 & 676.113 & 0,05 & 571.621 & 0,04 & 1.239 .216 & 0,09 & 4.436 .177 & 0,31 \\
\hline JAWA TENGAH & 7.724 .825 & 3.488 .230 & 0,45 & 142.897 & 0,02 & 581.181 & 0,08 & 1.563 .105 & & 2.279 .238 & 0,30 \\
\hline DI YOGYAKARTA & 1.848 .592 & 1.377 .801 & 0,75 & 7.928 & 0,00 & 99.929 & 0,05 & 247.908 & 0,13 & 206.091 & 0,11 \\
\hline JAWA TIMUR & 12.171 .292 & 1.447 .206 & 0,12 & 23.562 & 0,00 & 367.539 & 0,03 & 7.696 .004 & 0,63 & 2.636 .837 & 0,22 \\
\hline BANTEN & 837.917 & 488.351 & 0,58 & 116.554 & 0,14 & 27.361 & 0,03 & 143.471 & 0,17 & 62.181 & 0,07 \\
\hline BALI & 1.957 .400 & 698.171 & 0,36 & 532.729 & 0,27 & 38.769 & 0,02 & 88.009 & 0,04 & 599.721 & 0,31 \\
\hline NUSA TENGGARA BARAT & 2.802 .974 & 1.486 .111 & 0,53 & 595.655 & 0,21 & 34.466 & & 151.419 & 0,05 & 535.323 & 0,19 \\
\hline NUSA TENGGARA TIMUR & 746.425 & 274.837 & 0,37 & 84.372 & 0,11 & 0 & 0,00 & 209.856 & 0,28 & 177.360 & 0,24 \\
\hline KALIMANTAN BARAT & 384.620 & 170.576 & 0,44 & 107.860 & 0,28 & 6.271 & 0,02 & 60.950 & 0,16 & 22.177 & 0,06 \\
\hline KALIMANTAN TENGAH & 300.451 & 203.565 & 0,68 & 21.434 & 0,07 & 34.376 & 0,11 & 74.863 & 0,25 & 589 & 0,00 \\
\hline KALIMANTAN SELATAN & 2.221 .960 & 546.278 & 0,25 & 269.640 & 0,12 & 172.503 & 0,08 & 650.475 & 0,29 & 39.526 & 0,02 \\
\hline KALIMANTAN TIMUR & 824.659 & 273.177 & 0,33 & 79.379 & 0,10 & 230.493 & 0,28 & 12.552 & 0,02 & 229.058 & 0,28 \\
\hline SULAWESI UTARA & 296.100 & 115.575 & 0,39 & 116.101 & 0,39 & 3.598 & 0,01 & 47.703 & 0,16 & 13.123 & 0,04 \\
\hline SULAWESI TENGAH & 37.204 & 12.905 & 0,35 & 0 & 0,00 & 0 & 0,00 & 4.254 & 0,11 & 20.045 & 0,54 \\
\hline SULAWESI SELATAN & 586.524 & 169.112 & 0,29 & 279.967 & 0,48 & 44.705 & 0,08 & 19.918 & 0,03 & 72.821 & 0,12 \\
\hline
\end{tabular}


Agus T. dan Mukmin Z. Problematika Pengelolaan Tanah... 595

\begin{tabular}{|c|c|c|c|c|c|c|c|c|c|c|c|}
\hline SULAWESI TENGGARA & 276.121 & 159.926 & 0,58 & 30.420 & 0,11 & 0 & 0,00 & 70.331 & 0,25 & 15.444 & 0,06 \\
\hline GORONTALO & 72.172 & 47.600 & 0,66 & 14.626 & 0,20 & 0 & 0,00 & 8.573 & 0,12 & 1.373 & 0,02 \\
\hline SULAWESI BARAT & 2.802 .974 & 1.486 .111 & 0,53 & 595.655 & 0,21 & 34.466 & 0,01 & 151.419 & 0,05 & 535.323 & 0,19 \\
\hline MALUKU & 6.549 & 5.005 & 0,76 & 1.544 & 0,24 & 0 & 0,00 & 0 & 0,00 & 0 & 0,00 \\
\hline MALUKU UTARA & 533.331 & 328.925 & 0,62 & 89.654 & 0,17 & 0 & 0,00 & 46.277 & 0,09 & 68.475 & 0,13 \\
\hline PAPUA & 565.454 & 325.906 & 0,58 & 0 & 0,00 & 5.000 & 0,01 & 163.613 & 0,29 & 70.934 & 0,13 \\
\hline PAPUA BARAT & 163.457 & 163.457 & 1,00 & 0 & 0,00 & 0 & 0,00 & 0 & 0,00 & 0 & 0,00 \\
\hline $\mathrm{Jumlah}$ & 80.824 .725 & 43.690 .952 & 54,056 & 5.944 .176 & 7,35 & 4.263 .876 & 5,28 & 13.608 .726 & 16,84 & 13.224 .772 & 16,36 \\
\hline
\end{tabular}

Dari ragaan di atas, nampak bahwa pemanfaatan tanah wakaf di Indonesia, secara berurutan sebagai berikut:

Pertama, untuk keperluan tempat ibadah (masjid dan mushalla) dengan total luasan $43.690 .952 \mathrm{~m}^{2}$, atau 54,056 \% dari luas keseluruhan tanah wakaf di Indonesia. Kedua, untuk keperluan prasarana sekolah dengan total $13.608 .726 \mathrm{~m}^{2}$, atau $16,84 \%$ dari luas keseluruhan tanah wakaf di Indonesia. Ketiga, untuk keperluan wakaf sosial lainnya, dengan total luasan $13.224 .772 \mathrm{~m}^{2}$, atau $16,36 \%$ dari luas keseluruhan tanah wakaf di Indonesia. Keempat, untuk keperluan tanah pemakaman dengan total luasan $5.944 .176 \mathrm{~m}^{2}$, atau $7,35 \%$ dari luas keseluruhan tanah wakaf di Indonesia. Kelima, untuk keperluan pendididikan pesantren dengan total luasan 4.263.876 $\mathrm{m}^{2}$, atau 5,28\% dari luas keseluruhan tanah wakaf di Indonesia

Adapun untuk tiga propinsi dengan luasan tanah wakaf tertinggi secara nasional, yakni Propinsi Lampung, Jawa Barat dan Jawa Timur, proporsi pemanfaatan tanah wakafnya bervariasi. Propinsi Lampung, yang memiliki tanah wakaf seluas $20.134 .697 \mathrm{~m}^{2}$, atau setara dengan 201 hektar lebih, pemanfaatan tanah wakaf untuk prasarana peribadatan seluas 20.074.284, pesantren 8.935, keperluan sosial seluas 6.635, sedangkan untuk tanah makam dan sekolah kosong. Sedangkan yang kedua adalah Jawa Barat dengan luas 14.259.818 m². Ibadah 7.327.131, makam 676.113, pesantren 571.621, sekolah 1.239.216, lainnya 4.436.177. Baru kemudian yang ketiga disusul oleh Jawa Timur dengan luasan $12.171 .292 \mathrm{~m}^{2}$. Untuk prasarana ibadah 1.447.206, untuk makam 23.562, pesantren 367.539, sekolah 7.696.004 dan untuk keperluan sosial lainnya adalah 2.636.837.

Jadi jelaslah, bahwa pemanfaatan wakaf di Indonesia sangat didominasi oleh pemanfaatan guna keperluan prasarana ibadah, baru selanjutnya diikuti dengan peruntukan prasarana sekolah, wakaf sosial lainnya, pemakaman dan yang terakhir adalah untuk prasarana pondok pesantren. 
Dari potret pemanfaatan tanah wakaf di atas, nampak bahwa pemanfaatan guna keperluan prasarana ibadah, dalam hal ini masjid dan mushalla jumlahnya sangat dominan. Sedangkan sebaliknya, pemanfaatan untuk keperluan sosial di luar keempat itu semua menduduki urutan terrendah.

Memang pemanfaatan yang dominan untuk prasarana ibadah tersebut tidak menjadi masalah jika memang keperluan akan tempat ibadah masih dirasa penting dan proporsional. Tetapi jika pemanfaatan untuk keperluan ibadah tersebut dikarenakan oleh keinginan pewakaf yang orientasinya hanya untuk mengejar atau meraih keutamaan (fadhilah) bagi wakaf untuk kepentingan ibadah dengan tanpa mempedulikan kebutuhan dalam lingkungan setempat, maka pemanfaatannya menjadi tidak optimal. Misalnya jika di lingkungan tersebut telah tersedia tempat ibadah yang lebih dari mencukupi, maka sebaiknya pemanfaatan diorientasikan untuk pemanfaatan yang lebih produktif dan berdaya guna tinggi bagi umat Islam.

Memang dalam sajian data di atas, tidak ada item yang cecara khusus menyebutkan produktif atau tidaknya pemanfaatan tanah wakaf di suatu propinsi dan di level nasional. Namun jika melihat bahwa dalam klasifikasi keperluan sosial lainnya masih menjadi bagian yang terkecil, maka dapat disimpulkan bahwa wakaf yang berorientasi bisnis dan produktif masih rendah. Sekaligus sajian data yang ada tersebut belum mempertimbangkan secara serius penghitungan wakaf yang berorientasi bisnis dan produktif. Yang karenanya, sulit juga untuk memotret dari waktu ke waktu progress atau perkembangan dari pemanfaatan tanah yang berorientasi bisnis dan profit tersebut.

Dengan masih belum signifikannya pemanfaatan untuk kepentingan yang berorientasi bisnis dan produktif tersebut, maka menunjukkan bahwa pemahaman ajaran dan teologi perwakafan di Indonesia masih didominasi pola pemahaman lama, di mana wakaf selalu saja untuk tempat ibadah dan jika pun ada kecenderungan lain, maksimalnya baru dalam tataran untuk kepentingan pendidikan, ialah sekolah dan pesantren. Dengan istilah yang lain, tauhid sosial dan fiqih sosial belum mendapatkan perhatian yang memadai di kalangan umat Islam. Sedangkan, jika dilihat melalui pertimbangan kepentingan untuk kemajuan dan kesejahteraan umat Islam, maka tauhid dan fiqh sosial adalah mutlak diperlukan. 
Karena itu disseminasi dan edukasi terkait tauhid dan fiqih sosial ini masih sangat perlu untuk dikembangkan dan ditingkatkan.

Terkait dengan masih belum signifikan nya pemanfaaatan yang berorientasi pada bisnis dan produktif tersebut, menunjukkan bahwa umat Islam masih miskin inovasi bagi pengembangan dan pensejahteraan masyarakat. Di sini nampak kurang adanya pembaharuan dan terobosan yang sebenarnya sangat diperlukan bagi umat Islam. Untuk itulah, maka harus dilakukan upaya-upaya sebagai berikut:

Pertama, secara teologis, perlunya pencerahan yang simultan bagi masyarakat muslim akan keutamaan tauhid dan fiqih sosial dalam perwakafan. Sehingga, wakaf yang berorientasi untuk kepentingan kemajuan dan kesejahteraan umat akan menjadi suatu prioritas yang dilakukan secara kebersamaan di kalangan umat Islam.

Kedua, perbaikan dari segi prosedur dan mekanisme perwakafan. Dalam kepentingan perlunya peningkatan pemanfaatan tanah wakaf yang berorientasi pada kesejahteraan masyarakat, ialah wakaf yang yang bertujuan untuk keperluan bisnis dan produktif, perlu diberikan insentif dari segi prosedur dan mekanisme dalam proses wakaf produktif. Hal ini dapat dilakukan dengan cara mempermudah aplikasi proses pewakafan yang kepentingannya untuk produktif atau bisnis, ataupun memberi kemudahan bagi proses konversi pemanfaatan wakaf.

Ketiga, diperlukannya sinergi dari berbagai lembaga yang terkait dengan pengurusan proses dan prosedur wakaf serta pengelolaannya. Jika selama ini Kementerian Agama merupakan satu-satunya kementerian atau departemen yang mengurusinya, kalaupun Kantor Agraria terlibat itu pun dalam aspek yang sangat minimalis, maka semestinya dalam tahap selanjutnya, sinergi perlu diperkuat. Kementerian Agama, Kantor Agraria serta Departemen Perindakop (Perindustrian Perdagangan dan Koperasi) mestinya juga harus dilibatkan. Hal ini dimaksudkan agar semua pihak yang terkait dapat ikut berpartisipasi secara aktif bagi optimalisasi pemanfaatan tanah wakaf. 


\section{Kasus Pemberdayaan Tanah Wakaf}

Di tengah minimnya optimalisasi pemanfaatan tanah wakaf secara nasional, perlu dilihat di sini beberapa contoh pemanfaatan tanah wakaf yang optimal bagi kesejahteraan umat yang sudah berjalan di berbagai tempat di Indonesia. Dalam hal ini, penulis memberikan dua contoh kasus, ialah Pondok Modern Gontor Ponorogo dan Baitul Ashi yang berlokasi di Makkah yang dimiliki oleh Propinsi Nanggroe Aceh Darussalam.

\section{Pondok Modern Darussalam Gontor}

Pondok Modern Darussalam Gontor (PMDG) adalah sebuah pondok pesantren modern yang berpusat di desa Gontor, kecamatan Mlarak, Kabupaten Ponorogo. Didirikan oleh Trimurtinya (KH. Ahmad Zarkasyi, KH. Ahmad Sahal, dan KH. Zainudin Fananie) pada 1926, kini PMDG suah menginjak usia yang ke-69 tahun. Tak dapat dipungkiri bahwa PMDG mempunyai peran besar dalam dunia pesantren, ini terbukti dengan jumlah pondok alumninya yang mencapai 200 pondok di seluruh Indonesia.

Berdasarkan data di Warta Dunia PMDG vol. 67, jumlah keseluruhan santri dan guru PMDG mencapai 21.255 orang. Jumlah tersebut terbagi dalam satu Gontor pusat, dan 20 cabangnya, termasuk ISID (Isntitut Studi Islam Darussalam) yang tahun ini diproyeksikan menjadi Universitas Darussalam. Setiap tahunnya kurang lebih 4000 santri mengikuti ujian masuk PMDG. Akan tetapi dengan berbagai pertimbangan seperti keterbatasan tempat, standar kemampuan, dan lain-lain, banyak yang harus ditolak masuk. ${ }^{14}$

Salah satu yang menjadi kunci sukses Gontor sehingga bisa bertahan dan berkembang pesat sampai hari ini adalah nilai-nilai yang dipegang teguh oleh para penerusnya, yang diwariskan oleh paraTrimurti. Wakaf menjadi salah satunya. Dengan menjadikan Universitas Al-Azhar, yang merupakan salah satu Universitas tertua di dunia, sebagai contoh karena wakafnya, para trimurti mendeklarasikan pewakafan PMDG.Tujuannya antara lain adalah agar PMDG nantinya tidak akan Hijriyah.

14 Pondok Modern Gontor Ponorogo, Warta Dunia Pondok Modern Darussalam Gontor, volume 67 tahun 1435 
menjadi objek perebutan kekuasaaan antar keturunan Trimurti. Lalu kemudian dibentuk Badan Wakaf PMDG yang sekarang diketuai oleh K.H. Kafrawi Ridwan, M.A. Badan Wakaf PMDG mengadakan rapat dua tahun sekali. Rapat ini nantinya yang akan menentukan kebijakan PMDG sampai rapat yang berikutnya.

Jumlah seluruh tanah PMDG yang merupakan waqaf berkisar di angka 749 hektar, menurut keterangan Staf Yayasan PMDG, saudara Rifqi Indrawan. ${ }^{15}$ Tanah tersebut kemudian dimanfaatkan untuk berbagai macam keperluan PMDG, antara lain; pondok, lahan kelapa sawit, lahan sawah padi, dan lahan hutan jati. Adapun pengelolaan lahan-lahan sawah padi tersebut adalah dengan mempekerjakan mandor-mandor di lahan yang telah ditentukan. Kemudian mandor-mandor tersebut terus dipantau dan diawasi oleh staf Yasasan PMDG. Dan kemudian ketika panen, pihak pondok akan memberi upah kepada mador-mandor tersebut sesuai jumlah yang telah disepakati di awal.

Taksiran pendapatan pondok dari lahan tersebut adalah sebagai berikut; di Ngawi, jumlah tanah waqaf adalah 207 hektar, dengan sawah sebesar 22 hektar. Dari sawah di Ngawi tersebut setiap kali panen dapat menghasilkan kurang lebih 900 juta sampai dengan 1 milyar lebih setiap kali panen (laba), dengan 3 kali panen setiap tahunnya. Uang tersebut kemudian disimpan di kantor Admisitrasi di Gontor pusat. Pimpinan pondok dan Badan Wakaf mengontrol kelancaran proses ini dengan laporan rutin.

\section{Baitu Ashi}

Baitul Ashi adalah hal yang unik terjadi pada Propinsi Naggroe Aceh Darussalam. Baitul Ashi adalah aset tanah wakaf yang dimiliki oleh Pemerintah Daerah Propinsi NAD, namun uniknya tanah ini berlokasi di Makkah, Saudi Arabia. Dengan pemanfaatan Baitul Ashi ini, setiap jamaah haji yang berasal dari propinsi NAD mendapatkan uang cash dari pengelola Baitul Ashi. Pembagian uang pengganti ini dimulai tahun 2006, saat itu uang yang dibagikan sejumlah 6,5 juta

15 Wawancara dengan Rifqi Indrawan, Ustadz dan pengurus Bidang Wakaf Pondok Modern Darussalam Gontor, 8 Juli 2014. 
Riyal Saudi, tahun 2009, sebesar Rp 14,54 milyar yang dibagi dan setiap jamaah mendapat Rp 4.000.000,-..16

Baitul Ashi ini berasal dari tanah wakaf yang disumbangkan oleh seorang tokoh yang berasal dari Aceh dan sudah lama tinggal di Makkah. Tokoh tersebut bernama Habib Bugak Asyi. Wakaf itu dikukuhkan di hadapan hakim Mahkamah Syariyah Mekkah pada 18 Rabi'ul Akhir 1224 H atau tahun 1809 M. ${ }^{17}$ Habib Bugak asal Aceh datang ke Mekkah pada tahun $1223 \mathrm{H}$, dan membeli tanah sekitar Qusyasyiah yang sekarang berada di sekitar Bab Al-Fath. Saat itu masa kerajaan Utsmaniyah. Dan Saudi di bawah pimpinan Raja Malik Saud bin Abdul Aziz melakukan pengembangan Masjidil Haram, dan mengakibatkan tergusurnya rumah Habib Bugak. Penggusuran itu diberikan ganti rugi yang kemudian dibelikan tanah di dua lokasi lainnya. Di kedua lahan tersebut dibangun hotel bintang lima masing masing dengan kamar sekitar 350 unit dan sekitar 1000 unit. Aset wakaf tersebut terus berkembang dan mengasilkan banyak keuntungan.

Sebenarnya, tanah tersebut juga bukan milik pribadi Habib Bugak, tetapi milik kolektif para jamaah haji Aceh yang setiap tahunnya yang dikelola oleh beberapa orang Aceh di Makkah yang dipimpin oleh Habib Bugak, yang nama aslinya adalah Habib Abdurrahman bin Alwi al-Habsyi, atau Sayyid Abdurrahman bin Alwi Peusangan. ${ }^{18}$ Bahkan, lebih dari itu, sebenarnya wakaf Aceh di Makkah bukan hanya Baitul Asyi saja, namun banyak orang-orang Aceh yang mewakafkan tanah di Makkah. Selain wakaf di Makkah, tradisi wakaf di kalangan rakyat Aceh memang sudah ratusan tahun. Misalnya, dana wakaf untuk pembelian kapal perang Turki beserta biaya prajuritnya di Aceh, dana wakaf untuk biaya diplomasi Abdurrahman al-Zahir ke Singapura, Turki dan Arab, serta, pembelian pesawat Seulawah. ${ }^{19}$

${ }^{16}$ Interview dengan Putra, Baitul Mal, Pemerintah NAD, 7 September 2014, dipadukan dengan, Hasanudin Yusuf Adan, "Mengenal Wakaf dalam Konteks Ke-Aceh-an", dalam majalah Edukasi Zakat Baitul Mal Aceh, edisi I tahun 2013.

${ }^{17}$ Interview dengan Putra, Baitul Mal, Pemerintah NAD, 7 September 2014, dan Hasanudin, Ibid.

${ }^{18}$ Hasanudin, Ibid.

${ }^{19}$ Hasanudin, Ibid. 


\section{Problematika Dalam Pemberdayaan Wakaf}

Wakaf telah dilaksanakan berdasarkan paham yang dianut oleh sebagian besar masyarakat Indonesia, yaitu paham Syafi iyyah sebagaimana mereka mengikuti madzhabnya, seperti tentang: ikrarnya, harta yang boleh diwakafkan, dan boleh tidaknya tukar menukar harta wakaf.

Kerumitan aspek yuridis dalam perwakafan yang pertama adalah terkait proses sertifikasi. Tingginya tanah yang belum bersertifikat dikarenakan prosedur terkait permasalahan agraria masih dinilai sebagai hal yang relatif rumit bagi kebanyakan orang. Dengan keharusan melengkapi berbagai persyaratan sebenarnya cukup menyusahkan. Hal ini dibuktikan dengan masih banyaknya tanah wakaf yang belum bersertifikat sebagaimana nampak dalam tabel di atas.

Kedua, terkait dengan dengan konversi tanah wakaf. Aspek ini sebagaimana nampak dalam aturan dan sebagaimana nampak dalam flow chart di atas, ialah harus mendapatkan izin dari menteri dan Badan Wakaf Indonesia (BWI). Hal ini terntu bukan suatu hal yang sederhana. Bahkan, untuk kepentingan seperti itu memerlukan waktu yang bertahun-tahun, mengingat birokrasi di Indonesia yang masih belum dapat berjalan secara efisien. Karena itulah, maka diperlukan proses yang lebih sederhana.

Belum lagi di wilayah-wilayah yang terjadi kerusakan data secara masal, misalnya saja di daerah bencana. Banyak tanah wakaf yang kemudian hilang karena belum adanya sertifikat dan kurangnya saksi. Di Propinsi Nanggroe Aceh Darussalam misalnya, banyak tanah wakaf yang tidak diakui status wakafnya oleh ahli waris, sedangkan saksi sangat minim dan sertifikat tidak tersedia, sehingga akhirnya wakaf tadi diambil alih lagi oleh keluarganya. Pasca terjadinya musibah Tsunami di Aceh, penertiban wakaf menjadi masalah yang belum kunjung selesai. ${ }^{20}$ Karena miskinnya dokumen hukum juga, banyak tanah wakaf telah bergeser kepemilikan dan pengelolaannya. Misalnya, kompleks masjid Raya Baiturrahman di Aceh, pada awalnya memiliki area wakaf yang sangat luas. Bahkan kompleks yang hari ini telah menjadi pasar di Banda Aceh dan dikelola Pemda, sebenarnya adalah 
aset wakaf milik Masjid Raya. ${ }^{21}$ Lebih dari itu, tanah lapang yang sangat luas, Blang Padang, yang sekarang ini diidentikkan sebagai milik Departemen Pertahanan, sebenarnya juga merupakan aset wakaf dari Masjid Raya Baiturrahman.

Hal di atas, adalah salah contoh betapa pengurusan tanah wakaf bukan suatu hal yang sederhana. Juga bahwa keberpihakan berbagai instansi terkait, utamanya adalah Badan Pertanahan (BPN) masih jauh dari optimal. Hal ini sebenarnya dapat ditelusuri musababnya, adalah karena memang penanganan atau pengurusan tanah wakaf bukan sesuatu yang profitable, dalam arti memberikan keuntungan finansial secara langsung.

Dengan mempertimbangkan hal tersebut, maka perlu dilakukan perbaikan atas kebijakan agraria yang ada untuk kemudian menuju kebijakan agraria yang lebih Ideal. Kebijakan yang lebih ideal tersebut adalah yang memberikan penguatan pada: 1) Pemanfaatan tanah wakaf yang berfungsi bagi kesejahteraan dan pengentasan kemiskinan. Hal ini seharusnya menjadi prioritas dalam kebijakan agraria di Indonesia. Dapat dilakukan dengan memberikan berbagai kemudahan akses dan layanan, sehingga karena pengelola wakaf sifatnya adalah nirlaba, maka sudah sewajarnya pengurusannya haruslah mendapatkan banyak kemudahan. Ini tidak dapat disamakan dengan pengurusan legalitas tanah karena jual beli atau bentuk transaksi bisnis lainnya; 2) Memberikan insentif bagi pemanfaatan tanah untuk kepentingan produktif yang mendatangkan profit, yang hasil gunanya dimaksudkan untuk kepentingan sosial. Hal ini dimaksudkan untuk mendorong sebanyak mungkin aset wakaf diubah dari cost-center menjadi profit-center. Dengan kata lain, tanah wakaf yang sebelumnya dimanfaatkan untuk kepentingan yang memerlukan pendanaan, menjadi pemanfaatan yang justru menghasilkan keuntungan. Sehingga kesejahteraan umat akan dapat dicapai dengan kebijakan agraria yang semacam itu.

21 Wawancara dengan Fathurrahmi, Msi, Anggota persatuan Qori' dan Hafidh Masjid Baiturrahman, 7 September 2014. 


\section{Penutup}

Dari pemaparan dan diskusi di depan, diperoleh kesimpulan sebagai berikut:

Pertama, Institusi atau pranata wakaf memiliki peranan dalam perjalanan sejarah dan peradaban umat Islam. Berbagai lembaga wakaf telah berfungsi sebagai tempat penyebaran ilmu dan budaya, dan memberikan ruang bagi ulama, para ahli fikih dan budayawan untuk mengembangkan keilmuan dan keahliannya. Di antara lembaga-lembaga wakaf yang memiliki fungsi; sebagai tempat ibadah, pusat baca tulis, madrasah serta perpustakaan.

Kedua, Pemanfaatan tanah wakaf di Indonesia didominasi untuk keperluan tempat ibadah (masjid dan mushalla) dengan total luasan $43.690 .952 \mathrm{~m}^{2}$, atau 54,056 $\%$ dari luas keseluruhan tanah wakaf di Indonesia, kemudian untuk keperluan prasarana sekolah dengan total $13.608 .726 \mathrm{~m}^{2}$, atau $16,84 \%$ dari luas keseluruhan tanah wakaf di Indonesia, serta untuk keperluan wakaf sosial lainnya, dengan total luasan $13.224 .772 \mathrm{~m}^{2}$, atau $16,36 \%$ dari luas keseluruhan tanah wakaf di Indonesia, untuk keperluan tanah pemakaman dengan total luasan $5.944 .176 \mathrm{~m}^{2}$, atau $7,35 \%$ dari luas keseluruhan tanah wakaf di Indonesia, dan terakhir untuk keperluan pendididikan pesantren dengan total luasan $4.263 .876 \mathrm{~m}^{2}$, atau $5,28 \%$ dari luas keseluruhan tanah wakaf di Indonesia. Nampak bahwa dalam klasifikasi keperluan sosial lainnya masih menjadi bagian yang terkecil, maka dapat disimpulkan bahwa wakaf yang berorientasi bisnis dan produktif masih rendah. Sekaligus sajian data yang ada tersebut belum mempertimbangkan secara serius penghitungan wakaf yang berorientasi bisnis dan produktif.

Atas kesimpulan di atas, dapat diajukan saran-saran sebagai solusi permasalahan yang ada: pertama, dengan masih belum signifikannya pemanafaatan untuk kepentingan yang berorientasi bisnis dan produktif tersebut, maka menunjukkan bahwa pemahaman ajaran dan teologi perwakafan di Indonesia masih didominasi pola pemahaman lama, dengan istilah yang lain, tauhid sosial dan fiqih sosial belum mendapatnya perhatian yang memadai di kalangan umat Islam. Kedua, perlu dilakukan perbaikan atas kebijakan agraria yang ada untuk kemudian menuju kebijakan agraria yang lebih ideal. Kebijakan yang lebih ideal tersebut adalah yang 
memberikan penguatan pada: Pemanfaatan tanah wakaf yang berfungsi bagi kesejahteraan dan pengentasan kemiskinan. Serta Memberikan insentif bagi pemanfaatan tanah untuk kepentingan produktif yang mendatangkan profit, yang hasil gunanya dimaksudkan untuk kepentingan sosial. Hal ini dimaksudkan untuk mendorong sebanyak mungkin aset wakaf diubah dari cost-center menjadi profitcenter. Dengan kata lain, tanah wakaf yang sebelumnya dimanfaatkan untuk kepentingan yang memerlukan pendanaan, menjadi pemanfaatan yang justeru menghasilkan keuntungan. Sehingga kesejahteraan umat akan dapat dicapai dengan kebijakan agraria yang semacam itu.

\section{Daftar Pustaka}

al-Farj Abdurrahman ibn 'Ali Ibnu al-Jauzy, Abu, al-Muntazham fi Tārìkh al-Mulūk wa al-Umam, Dā’irah al-Ma'ārif al-Utsmaniyah, Haidarabd, 8/22/1359 H

Abdurrahman, Masalah Perwakafan Tanah Milik dan Kedudukan Tanah Wakaf Di Negara Kita, Citra Aditya Bakti, Bandung, 1994.

Zahrah, Abu, dalam Direktot Jendral Bimas Islam dan Penyelenggaraan haji, Panduan Pemberdayaan Tanah Wakaf Produktif Strategis di Indonesia, terbitan: Direktorat Pemberdayaan Wakaf Dirjen Bimas Islam, Depag RI., 2008.

Djunaidi, Achmad, Thobieb Al-Asyhar, Menuju Era Wakaf Produktif, Mitra Abadi Press, Jakarta, cet pertama, 2005.

Triyanta, Agus, "Wakaf Produktif: Dari Muamalah Klasik Menuju Inovasi Kontemporer." Makalah Disampaikan dalam Workshop Pengelolaan Wakaf Produktif (Pendekatan Pemberdayaan Kaum Mustadh'afin) pada tanggal 2 Agustus 2009 di Aula DPRD Kabupaten Sleman, diselenggarakan oleh Yayasan Ikhtiar Sejahtera, Tempel, Sleman, 2009.

Azhar Basyir, Ahmad, Garis-Garis Besar Sistem Ekonomi Islam, Badan Penerbit Fakultas Ekonomi UGM, Yogyakarta, tt.

al-Hanafy, Al-Kasany, Bada'I al-shanai, Juz VIII, Mustafa al-Bab al-Halabi wa Auladuh, Mesir, tt.

Asharinnuha, Fungsi Pendayagunaan dan Pemanfaatan Tanah Wakaf Menurut Peraturan Pemerintah No 28 Tahun 1977, tesis, Program Magister Kenotariatan, Program Pasca Sarjana, Universitas Diponegoro, Semarang, 2005.

Asrori, Manfaat dan Hambatan Dalam Penglolaan Wakaf Uang, disampaikan dalam acara pembinaan dan sosialisasi wakaf bagi pengelola wakaf kota Dumai yang dilaksanakan oleh kementerian Agama kota Dumai di hotel comfort Dumai pada tanggal 11 Desember, 2013. 
Munawir, A.W., Kamus Al-Munawir Arab-Indonesia, Pustaka Progresif, Yogyakarta, cet ke-14, tt.

Yunus, Mahmud, Kamus Arab-Indonesia, yayasan penyelenggara penterjemah/penafsir Al-Qur'an RI, Jakarta, 1994.

Departemen Agama RI, Al-Quran Dan Terjemah, PT. Tanjung Mas Inti, Semarang,1992.

Departemen Agama, Fiqih Wakaf, Direktorat Pengembangan Zakat Dan Wakaf, Jakarta, 2005.

Depag RI, Perkembangan Pengelolaan Wakaf di Indonesia, Dirjen Bimas Islam dan Penyelenggaraan Haji, Jakarta, 2004.

Pondok Modern Gontor Ponorogo, Warta Dunia Pondok Modern Darussalam Gontor, volume $67,1435 \mathrm{H}$.

Direktorat Jenderal Bimbingan Masyarakat Islam, Sistem Informasi Wakaf, pada http:/ / simbi.kemenag.go.id/siwak/ akses, 1 Agustus 2014.

Setia Tunggal, Hadi, Undang-Undang RI No 41 tahun 2004 Tentang Wakaf, Harvarindo, Jakarta, 2005.

Nasution, Harun, et all. Ensiklopedi Islam Indonesia, Djambatan, Jakarta,1992.

Daud Ali, Muhammad, Sistem Ekonomi Islam Zakat dan Wakaf, UI-Press, Jakarta,1988.

Suhendi, Hendi, Figh Muammalah, PT Raja Grafindo Persada, Jakarta, 2002.

Muslim bin al-Hajj al-qusairy, Imam, Shahih Muslim, Jilid III, Usaha Keluarga, Semarang, tt.

Hajar Asqalany Al-Hafidh, Ibnu, Bulughul Maram, Al-Ma'arif, Bandung, 1993.

Muslim bin al-Hajjaj al-Qusairy, Imam, Shahih Muslim, Juz II, Usaha Keluarga, Semarang, $\mathrm{tt}$.

Yusuf Adan, Hasanudin, "Mengenal Wakaf dalam Konteks Ke-Aceh-an", dalam majalah Edukasi Zakat Baitul Mal Aceh, edisi I tahun 2013.

S. Praja, Juhaya, Perwakafan di Indonesia,Yayasan Piara (Pengembangan Ilmu Agama dan Humaniora), Bandung,1997.

Hasbi Ash-Shiddieqy, M., Tafsir Al-Qur'anul Majied "An-Nur", Juz 1, Bulan Bintang, Cet. II, Jakarta, 1965.

Quraish Shihab, M., Tafsir Al-Mishbah (Pesan, Kesan dan Keserasian Al-Qur'an), Juz 1, Lentera Hati, Cet. II, Jakarta, 2004.

Abdullah Anan, Muhammad, Tārīkh al-Jāmi' al-Azhar, Majalah al- Risālah, edisi 136 Dzulqo'dah, $1345 \mathrm{H}$.

Abu Zahrah, Muhammad, Muhadlarah Fi al-Waqfi, Dar al-Fikr al-Arabiy, Mesir, 1971.

Fadlullah. B.T.H, Brendgeest, Muhammad, Kamus Arab-Melayu, Balai Pustaka, Jilid I, tt. 
Sabiq, Sayyid, Fiqih Sunnah, Al-Ma'arif, Bandung 1997.

ibn Ahmad ibn Shālih al-Shalih, Muhammad, al-Waqf fi al-Syarīah wa Atsruhu fi Tanmiyah al-Mujtama', Fihrisah Maktabah al-Malik Fahd al-Wathaniyah, Saudi Arabia, 2001.

Qahaf, Mundzir, Manajemen Wakaf Produktif, Khalifa, Cet-1, Jakarta, 2005.

Qohaf, Mundir, Al-Waqof al-Islami, Dar al-Fikr, cet I, Beirut, tt.

al-Siba'i, Mushtafa, Min Rawā' I' Hadāratina, Dar al-Warraq, $1420 \mathrm{H}$.

Hammami, Taufik, Perwakafan Tanah dalam Politik Hukum Agraria Nasional, PT. Tatanusa, Jakarta, 2003.

Tim Redaksi Fokusmedia, Kompilasi Hukum Islam, Fokusmedia, cet. ke-1, Bandung, 2005.

ibn Abdullah al-Hamawy, Yaqut, Mu'jam al-Udaba', Dār al- Ma'mun, Kairo, 1938.

Qardhawi, Yusuf, Fiqh Prioritas: Urutan Amal Yang Terpenting Dari Yang Penting, Terjemah, Gema Insani Press, Jakarta, 1996.

bin Abd. Aziz Al-Maribari, Zaenudin, Fath al-Mu'in, PT. Toha Putra, Semarang, (t.th).

Undang-Undang Pokok Agraria No. 5 Tahun 1960 tentang Peraturan Dasar PokokPokok Agraria

Undang-Undang no 41 tahun 2004 tentang Wakaf.

Peraturan Pemerintah Republik Indonesia Nomor 42 Tahun 2006 Tentang

Pelaksanaan Undang Undang Nomor 41 Tahun 2004 Tentang Wakaf

Wawancara dengan Rifqi Indrawan, Ustadz dan pengurus Bidang Wakaf Pondok Modern Darussalam Gontor, 8 Juli 2014.

Wawancara dengan Anggota persatuan Qori' dan Hafidh Masjid Baiturrahman, 7 September 2014.

Wawancara dengan Bpk Putra Misbah, Kepala Bidang Perwalian,Baitul Mal Aceh, 8 September 2014 